\title{
ANALYSIS OF POPULATION AND TAXONOMICAL STRUCTURE OF ATLANTIC COD, GADUS MORHUA (ACTINOPTERYGII: GADIFORMES: GADIDAE) FROM THE BALTIC SEA WITH USE OF MICROSATELLITE DNA
}

\author{
Agnieszka KIJEWSKA $^{1 *}$, Beata WIĘCASZEK ${ }^{2}$, and Tomasz KIJEWSKI ${ }^{1}$ \\ ${ }^{1}$ Department of Genetics and Marine Biotechnology, Institute of Oceanology PAS, Sopot, Poland \\ ${ }^{2}$ Division of Hydrobiology, Ichthyology and Biotechnology of Breeding, Faculty of Food Sciences and Fisheries, \\ West Pomeranian University of Technology, Kazimierza Królewicza 4, 71-550 Szczecin, Poland
}

Kijewska A., Więcaszek B., Kijewski T. 2011. Analysis of population and taxonomical structure of Atlantic cod, Gadus morhua (Actinopterygii: Gadiformes: Gadidae) from the Baltic Sea with use of microsatellite DNA. Acta Ichthyol. Piscat. 41 (4): 307-314.

\begin{abstract}
Background. Substantial declines in biomass of Atlantic cod, Gadus morhua L., one of the most valuable commercial fish species in the north Atlantic (including the Baltic Sea), has been observed in recent decades. A comprehensive understanding of the population structure contributes to proper management and conservation of genetic resources. We attempted to answer the question whether there exists differentiation among localized samples, and if so, whether this separation is large enough to warrant the recognition of distinct clades in cod as well as whether these distinct clades correspond to traditionally described regions of spawning and nursery areas or even stocks.

Materials and methods. Six microsatellites were used for finding differentiation between four sampling areas of G. morhua) from the Baltic Sea (Puck Bay, Bay of Gdańsk, Pomeranian Bay, and Øresund) and two from the north-eastern Atlantic (North Sea and Barents Sea). Genetic differences among localities were estimated with $F_{\text {ST }}$ using Weir and Cockerham's estimator $\theta$. Genetic distances among samples were calculated and visualized by multidimensional scaling using XLStat (Addinsoft).

Results. There is a statistically supported structure pattern among sampling localities from the Baltic Sea. One of them is related to the population from the Barents Sea, second is mixing with cod migrating from the North Sea. Conclusion. The level of heterozygosity and slight heterozygote deficiency suggest that, in case of all samples, we observed an isolation processes that could be an effect of withering or weakening the migrations between separate breeding stocks. This effect is most apparent for the most eastern populations from the Puck Bay and the Gulf of Gdańsk.
\end{abstract}

Keywords: Atlantic cod, Gadus morhua, microsatellites, Baltic Sea, north-eastern Atlantic

\section{INTRODUCTION}

A substantial decline in biomass of the Atlantic cod, Gadus morhua L., 1758, populations has been observed in recent decades. It might be related to overfishing and climate changes, as there has been an increase of average surface water temperature in some areas (e.g., North Sea) (Hutchinson et al. 2003). Since 1999, a plan for a longterm management of the cod stocks in the North Atlantic has been implemented by the EU and other countries. The plan was intended to reduce the fishing activity to sustain biological limits and to ensure spawning biomass for each stock. Twenty-seven main stocks of cod were recognized in the North Atlantic (Marteinsdóttir et al. 2005). Evolutionary effects of cod fisheries were documented using eco-genetic models (Eikeset et al. 2005). These effects are yet to be studied and understood in wild popu- lations with the application of a variety of genetic and molecular markers. Comprehensive understanding of population structure contributes to proper conservation of genetic resources. The extremely high fecundity of cod may cause non-equilibrium behaviour in genetic structure at certain levels (Árnason et al. 2004).

Large scale geographic differentiation of the north eastern and north western Atlantic Ocean cod populations were ascertained by allozyme analysis and nuclear restriction fragment length polymorphism (RFLP) of anonymous cDNA loci (Mork et al. 1985, Pogson et al. 1995) and by studies of allele frequencies at pantophysin I locus (Case et al. 2005). Geographic differentiation on smaller scale, i.e., within eastern or western Atlantic populations were found most successfully at the blood protein loci (Dahle and Jørstad 1993), pantophysin I alleles (Case et al. 2005),

\footnotetext{
* Correspondence: Dr Agnieszka Kijewska, Zakład Genetyki i Biotechnologii Morskiej, Instytut Oceanologii PAN, Sopot, Poland, Powstanców Warszawy 55, 81-712 Sopot, Poland, phone: (+48) 58-731-1759, fax: (+48) 58-551-2130, e-mail: agnes@iopan.gda.pl.
} 
nuclear RFLP (Pogson et al. 2001), and microsatellites (Beacham et al. 2002, Nielsen et al. 2003). Microgeographic differentiation can be best identified by microsatellites (Knutsen et al. 2003, Nielsen et al. 2003), but also at other loci as pantophysin I and hemoglobin (Jónsdóttir at al. 1999, Karlsson and Mork 2005). Consequently, more stocks of cod can be defined as separate management units (Hutchinson et al. 2003).

The objective of this study was to test the hypothesis that differentiation among closely localized samples is strong enough to educe subunits of cod populations according to traditionally described regions of spawning and nursery areas or even stocks.

\section{MATERIAL AND METHODS}

Research area and samples. A total of 230 of cod specimens sampled from the Pomeranian Bay, Puck Bay, Bay of Gdańsk, Øresund, North Sea (Flamborough Head), and Barents Sea (Bear Isle) were examined. The relevant details are shown in Table 1 and Fig. 1. Samples were collected by scientific- or commercial trawlers within 2002 and 2006.

Sample preparation. Fragments of fins and muscles with skin of adult fish were collected from all fish sampled. Genomic DNA from ca. $0.05 \mathrm{~g}$ of somatic tissue was isolated by a SDS/proteinase $\mathrm{K}$ and phenol/chloroform procedure (Sambrook et al. 1989).

Six polymorphic microsatellite loci were amplified using appropriate primers (Table 2). Each PCR reaction was performed in a total volume of $20 \mu \mathrm{L}$ containing $2 \mathrm{ng}$ of isolated DNA. Thirty cycles were performed for each pair of primers, with $1 \mathrm{~min}$ denaturation at $94^{\circ} \mathrm{C}(5 \mathrm{~min}$ in the first cycle), $30 \mathrm{~s}$ annealing at $57.3^{\circ} \mathrm{C}$ and $30 \mathrm{~s}$ extension at $72^{\circ} \mathrm{C}$ ( 5 min in the last cycle). The amplified DNA fragments were checked on 3.5\% high-resolution agarose (MetaPhor, Lonza) gel for mtDNA length variants. DNA bands were UV-visualized by ethidium bromide staining (Sambrook et al. 1989). Gel images were captured using video camera and an appropriate frame grabber (Scion Image for Windows beta 4.0.2, Scion Corporation, MA, USA).

All computations concerning Hardy-Weinberg equilibrium were performed using the software GENEPOP (Raymond and Rousset 1995). Amounts of genetic variation within sampling localities were characterized by the observed $\left(H_{\mathrm{O}}\right)$ and expected $\left(H_{\mathrm{E}}\right)$ heterozygosities and by allele richness at each locus separately; significance was calculated with Chi-square test. Null allele estimation was provided with estimator of Brookfield (1996). Genetic differences among localities were estimated with $F_{\text {ST }}$ using Weir and Cockerham's (1984) estimator $\theta$, both over all samples and between pairs of samples. Slatkin's $R_{\mathrm{ST}}$ was not used because the number of analysed loci was smaller than $20, F_{\mathrm{ST}}$ is considered more reliable under such circumstances (Gaggiotti et al. 1999). The $F_{\text {ST }}$ was calculated as implemented in ARLEQIUN ver. 3.5 (Excoffier et al. 2005). Genetic distances ( $D$; Nei 1983) among samples were estimated and visualized by multidimensional scaling using XLStat (Addinsoft). To obtain bootstrap support for observed structure the following procedure was applied. A matrix of Reynolds' distances (Reynolds et al. 1983) was multiplied using the SEQBOOT procedure and obtained matrix was computed using the GENEDIST procedure of the PHYLIP software (Felsenstein 2004). The output matrixes were used in the NEIGHBOR procedure to infer a neighbour joining (NJ) tree (Saitou and Nei 1987).

\section{RESULTS}

Genetic variation was moderate and in case of Baltic samples, similar to those presented by Nielsen et al. (2003). The $F_{\mathrm{ST}}$ was at level of 0.044 with $P<10^{-5}$ for total dataset. Similar value of $F_{\mathrm{SC}} 0.040, P<10^{-5}$ was computed as a measure of variation among populations and the level of inter group variation was very low $\left(F_{\mathrm{CT}}=0.004\right)$ and not significant. All pairwise $F_{\mathrm{ST}}$ differences were significant with $P$-values $<0.0001$ (Table 3 ). A little bit surprising was the $F_{\mathrm{ST}}$ difference between the Puck Bay vs. the Gulf of Gdańsk and the Pomeranian Bay, which are much higher than the differences between all other samples. Generally one locus displayed lower level of polymorphism as compared to Nielsen et al. (2003) resultsGmo8 while Gmo19 had slightly more alleles than it was noted in previous analyses. We have identified 37 private alleles at global mean frequency of 0.019 . The Pomeranian Bay has 10 of them, Øresund 8, Puck Bay 2, and Gulf of Gdańsk only one. While Tch12 appears to show the largest $F_{\mathrm{ST}}(0.100)$ with $P$-value $<0.001$, Gmo35 appears to be the last discriminatory locus $\left(F_{\mathrm{ST}}=0.021\right)$ and largest $P$-value (0.04) (Table 4).

Table 1

Characteristics of the samples of cod, Gadus morhua, collected by bottom-trawling

\begin{tabular}{|c|c|c|c|c|c|c|}
\hline \multirow{2}{*}{$\begin{array}{l}\text { Fishing area } \\
\text { (code) }\end{array}$} & \multicolumn{3}{|c|}{ Baltic Sea III d ICES } & \multirow{2}{*}{$\begin{array}{c}\text { Øresund III b } \\
\text { ICES } \\
\text { Øresund } \\
\text { SD } 23 \text { (ØRE) }\end{array}$} & \multirow{2}{*}{$\begin{array}{l}\text { North Sea IV } \\
\text { ICES } \\
\text { Flamborough } \\
\text { Head (NOR) }\end{array}$} & \multirow{2}{*}{$\begin{array}{c}\text { Barents SeaII b } \\
\text { ICES }\end{array}$} \\
\hline & $\begin{array}{c}\text { Puck Bay } \\
\text { SD } 26 \text { (PUC) }\end{array}$ & $\begin{array}{l}\text { Gulf of Gdańsk } \\
\text { SD } 26 \text { (GDA) }\end{array}$ & $\begin{array}{l}\text { Pomeranian Bay } \\
\text { SD } 24 \text { (POM) }\end{array}$ & & & \\
\hline Date of sampling & June 2006 & Dec. 2003 & Dec. 2005 & 20 Oct. 2004 & Oct. 2005 & April 2002 \\
\hline Geographic position & $\begin{array}{l}54^{\circ} 41^{\prime} \mathrm{N} \\
18^{\circ} 40^{\prime} \mathrm{E}\end{array}$ & $\begin{array}{l}54^{\circ} 28^{\prime} \mathrm{N} \\
18^{\circ} 42^{\prime} \mathrm{E}\end{array}$ & $\begin{array}{l}54^{\circ} 02^{\prime} \mathrm{N} \\
14^{\circ} 20^{\prime} \mathrm{E}\end{array}$ & $\begin{array}{l}55^{\circ} 49^{\prime} \mathrm{N} \\
12^{\circ} 42^{\prime} \mathrm{E}\end{array}$ & $\begin{array}{c}54^{\circ} 06^{\prime} \mathrm{N} \\
00^{\circ} 03^{\prime} \mathrm{E}\end{array}$ & $\begin{array}{l}73^{\circ} 30^{\prime} \mathrm{N} \\
19^{\circ} 00^{\prime} \mathrm{E}\end{array}$ \\
\hline Depth (m) & 3 & 30 & $10-12$ & 30 & - & 300 \\
\hline No. of hauls & 1 & 1 & 1 & 3 & 1 & 3 \\
\hline Range of age & I-IV & IV-VI & IV-VI & IV-VI & IV-VI & III-V \\
\hline No. of specimens & 30 & 25 & 25 & 50 & 50 & 50 \\
\hline
\end{tabular}

$\mathrm{SD}=$ ICES subdivision . 
The unrooted neighbour-joining tree inferred from Reynolds genetic distances shows Baltic populations more differentiated than between population from Øresund and the North Sea or the Barents Sea (Fig. 2). Nonetheless, the biggest significant difference is observed between sampling localities from the Baltic Sea and samples from Danish Straits, the North Sea and the Barents Sea.

Genetic differentiation between samples from the Baltic Sea and from Øresund, the North Sea and the Barents Sea is well visible on MDA plot, which displays that genetic distances between samples correlate with geographic distances. The first dimension may represent similarities between Barents and sampling localities from the eastern Baltic Sea, while second axis represents split between Baltic sampling localities and outer samples
(Fig. 3) according to the geographical distances. Comparing it to the unrooted tree and other data including $F_{\mathrm{ST}}$, more probable is that 1 st dimension represents reliable geographical and genetic arrangement.

The genetic diversity level was high, the total number of alleles varied between 13 for Gmo35 and 31 for Gmo8. All samples revealed heterozygote deficiency, for most of them the Hardy-Weinberg equilibrium was statistically significant (Table 5). The level of heterozygosity for Tch12 was generally lower than for other loci but in the Gulf of Gdańsk only four alleles were found and it appeared to be exclusively homozygotic for this locus. Thus, the Gulf of Gdańsk and Puck Bay appears to be more homozygotic than any other Baltic population (mean 0.49). We have observed a number of null alleles

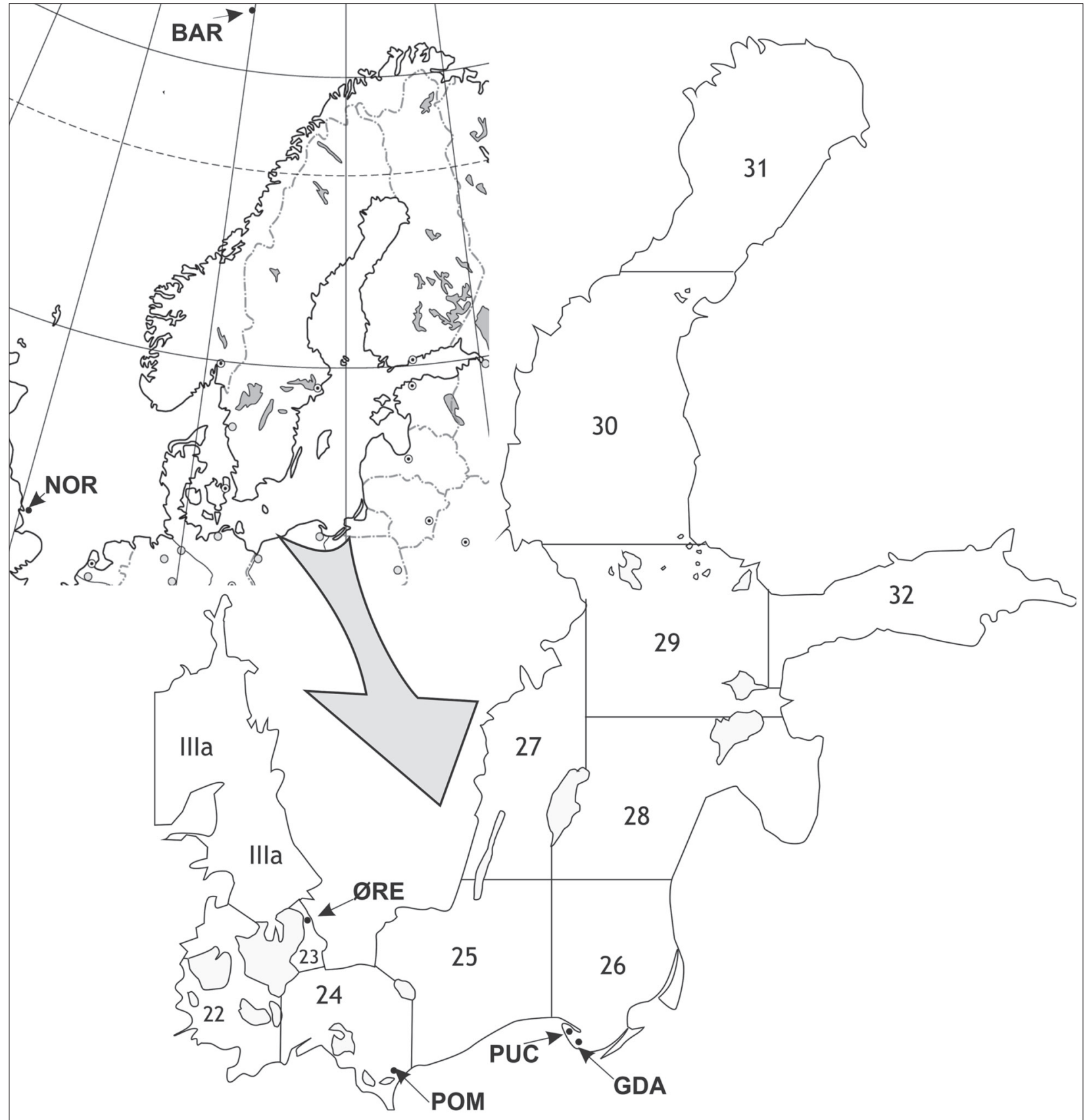

Fig. 1. Sampling localities of cod, Gadus morhua: GDA = Gdańsk Bay, PUC = Puck Bay, POM = Pomeranian Bay, $\varnothing \mathrm{RE}=$ Øresund, NOR $=$ the North Sea, Flamborough Head, BAR $=$ the Barents Sea 
in all loci, most for Tch12 locus. To estimate if the null allele problem affects results of Hardy-Weinberg disequilibrium we used the method of Brookfield (1996) to calculate the expected frequency $r$ of null alleles per locus from our total sample of 245 individuals. Obtained results showed that presence of null alleles did not affect parameters in consideration. These results suggest that null alleles are unlikely to be cause of the observed heterozygote deficiency in our data.

\section{DISCUSSION}

In many of the studies which have been conducted on invertebrates and fish, microsatellites revealed heterozygote deficiency (Knutsen et al. 2003, Nielsen et al. 2003). The deficiency can be, in this case, an artefact resulting from frequent null alleles or the result of inbreeding or reduction of mating populations. The latter factor is less probable in case of species that are widely distributed and consisting of many subpopulations (Hoarau et al. 2002). What also is important, the heterozygotes deficiency can reveal the fact that at the time of sampling, one could col- lect individuals from one shoal of fish belonging to same spawn. So in case of heterozygote deficiency, we assume that each sample was taken from one population characterized by the overdominance of specific alleles. Moreover, some loci are limited to few alleles and their $F_{\mathrm{ST}}$ estimates depend on sample and their geographical origin (Karlsson and Mork 2005). In the analyzed Baltic populations, microsatellite Tch12 is almost non-differentiating. Similar situation was described by Knutsen et al. (2003) for Atlantic cod from Skagerrak. Microsatellite Gmo19 described by O'Leary et al. (2007) as was also locus characterized with slight deficit of heterozygotes for the Barents Sea sample. We found deficit of heterozygotes for the Barents Sea, Pomeranian Bay and for the Gulf of Gdańsk. Nonetheless, all loci have significant $F_{\mathrm{ST}}$ values.

We have observed non-random distribution of genotypes for of all loci, supporting the interpretation of heterozygotes deficiency. O'Leary et al. (2007) found that Atlantic cod population is structured across the species range; the Baltic Sea population was recognized as the most differentiated from the Atlantic populations. These

Primer sequences and polymorphism characteristics of microsatellite loci of cod, Gadus morhua

\begin{tabular}{|c|c|c|c|c|}
\hline Locus & Sequence & Primers $\left(5^{\prime}-3^{\prime}\right)$ & $\begin{array}{l}\text { Size } \\
{[\mathrm{bp}]}\end{array}$ & GenBank Accession number \\
\hline $\mathrm{Gmo}^{1}$ & GACA & $\begin{array}{l}\text { R: TGGGGGAGGCATCTGTCATTCA } \\
\text { F: GCAAAACGAGATGCACAGACACC }\end{array}$ & $110-205$ & AF159238 \\
\hline Gmo19 ${ }^{1}$ & GACA & $\begin{array}{l}\text { R: GTCTTGCCTGTAAGTCAGCTTG } \\
\text { F: CACAGTGAAGTGAACCCACTG }\end{array}$ & $120-220$ & AF159232 \\
\hline Gmo35 & ACC & $\begin{array}{l}\text { R: CCTTATCATGTACGTTGTTAAC } \\
\text { F: GGAGGTGCTTTGAAGATG }\end{array}$ & $110-145$ & AF159235 \\
\hline Gmo3 $37^{1}$ & GACA & $\begin{array}{l}\text { R: CGTGGGATACATGGGTACCT } \\
\text { F: GGCCAATGTTTCATAACTCT }\end{array}$ & $220-290$ & AF159237 \\
\hline Tch11 & GATA & $\begin{array}{l}\text { R: TCG AGT TCA GGT GGA CAA } \\
\text { F: ATC CAT TGG TGT TTC AAC }\end{array}$ & $121-193$ & AF178501 \\
\hline $\operatorname{Tch} 12^{2}$ & GGTT & $\begin{array}{l}\text { R: AGTACAGCTTGATTGTTTCTGGG } \\
\text { F: CAATTTGTCAGCCTCTGTTACC }\end{array}$ & $122-146$ & AF178502 \\
\hline
\end{tabular}

${ }^{1}$ primers designed by Miller et al. (2000); ${ }^{2}$ primers designed by O'Reilly et al. (2000); R = reverse primer; $\mathrm{F}=$ forward primer.

Table 3

Estimates of pairwise $F_{\mathrm{ST}}$ among samples of cod, Gadus morhua,

(below diagonal) and $P$-values (above diagonal)

\begin{tabular}{lcccccc}
\hline Sampling locality & PUC & GDA & POM & ØRE & NOR & BAR \\
\hline Puck Bay (PUC) & & $<0.00001$ & $<0.00001$ & $<0.00001$ & $<0.00001$ & $<0.00001$ \\
Gulf of Gdańsk (GDA) & 0.07072 & & $<0.00001$ & $<0.00001$ & $<0.00001$ & $<0.00001$ \\
Pomeranian Bay (POM) & 0.06338 & 0.04135 & & $<0.00001$ & $<0.00001$ & $<0.00001$ \\
Øresund (ØRE) & 0.05186 & 0.03857 & 0.04723 & & $<0.00001$ & $<0.00001$ \\
North Sea (NOR) & 0.05544 & 0.02467 & 0.04700 & 0.02523 & & $<0.00001$ \\
Barents Sea (BAR) & 0.04982 & 0.04210 & 0.04135 & 0.04441 & 0.02623 & \\
\hline
\end{tabular}

Table 4

Single and multilocus estimates of $F_{\mathrm{ST}}$ and associated $P$-values for samples of cod, Gadus morhua

\begin{tabular}{lcccccccc}
\hline & \multicolumn{9}{c}{ Locus } & & \\
\cline { 2 - 7 } & Gmo8 & Gmo19 & Gmo35 & Gmo37 & Tch11 & Tch12 & Overall \\
\hline$F_{\text {ST }}$ & 0.046 & 0.027 & 0.021 & 0.044 & 0.078 & 0.100 & 0.052 \\
$P$-value & $<0.001$ & 0.001 & 0.040 & $<0.001$ & $<0.001$ & $<0.001$ & $<0.001$ \\
\hline
\end{tabular}


findings were confirmed using wide range of genetic markers (Pogson et al. 1995, O'Leary et al. 2006). Here we show that population structure was also identified within the Baltic Sea itself, with the Puck Bay population appearing to be the most differentiated from others analyzed in this study. The differentiation between the Puck Bay and the other samples is an effect of higher homogeneity of this sample. Other reason, postulated by some authors, could be the difference between Atlantic cod from the central- and the eastern Baltic Sea including ICES subdivision 26. The eastern cod characteristics are closely related to those of the Barents Sea population (Sick 1965, Sobecka 2007). In contrast, Nielsen et al. (2003) presented data supporting hypothesis that the Baltic cod is the most related to the North Sea population. The differentiation between the Baltic Sea populations may solve these inconsistencies. The western Baltic populations are strongly influenced by the North Sea cod whilst the eastern population is "older" and still shares some features with the population from the Barents Sea. This hypothesis is supported by our own results, where the lowest genetic differentiation was observed between the Puck Bay and the sample from the Barents Sea (0.0498). Additionally, the Øresund sample is more closely related to the sample from the Puck Bay than the Gulf of Gdańsk. Nielsen et al. (2003), using 9 microsatellite loci found that in the Danish Strait cod is the hybrid swarm as an effect of mixing of western and eastern Atlantic cod. The same author suggested that the level of mixing of these subpopulations and the outreach of the hybrid zone depends on the level the North Sea water inflows towards the eastern Baltic. Also Bleil and Oeberst (2002) suggested that in the Arkona basin (Baltic; lat $54^{\circ} 41^{\prime} \mathrm{N}$, long $13^{\circ} 26^{\prime} \mathrm{E}$ ) two cod subspecies: Gadus morhua morhua L., 1758 and G. morhua callarias L., 1758 mix during the spring and summer spawn. Consequently those authors proposed the theory that western stock is represented mainly by the Belt Sea cod subspecies ( $G$. morhua morhua), while the eastern stock is represents mainly by the Baltic cod ( $G$. morhua callarias). These could clarify the status of Øresund sample if we accept that it represents separate stock of well mixed

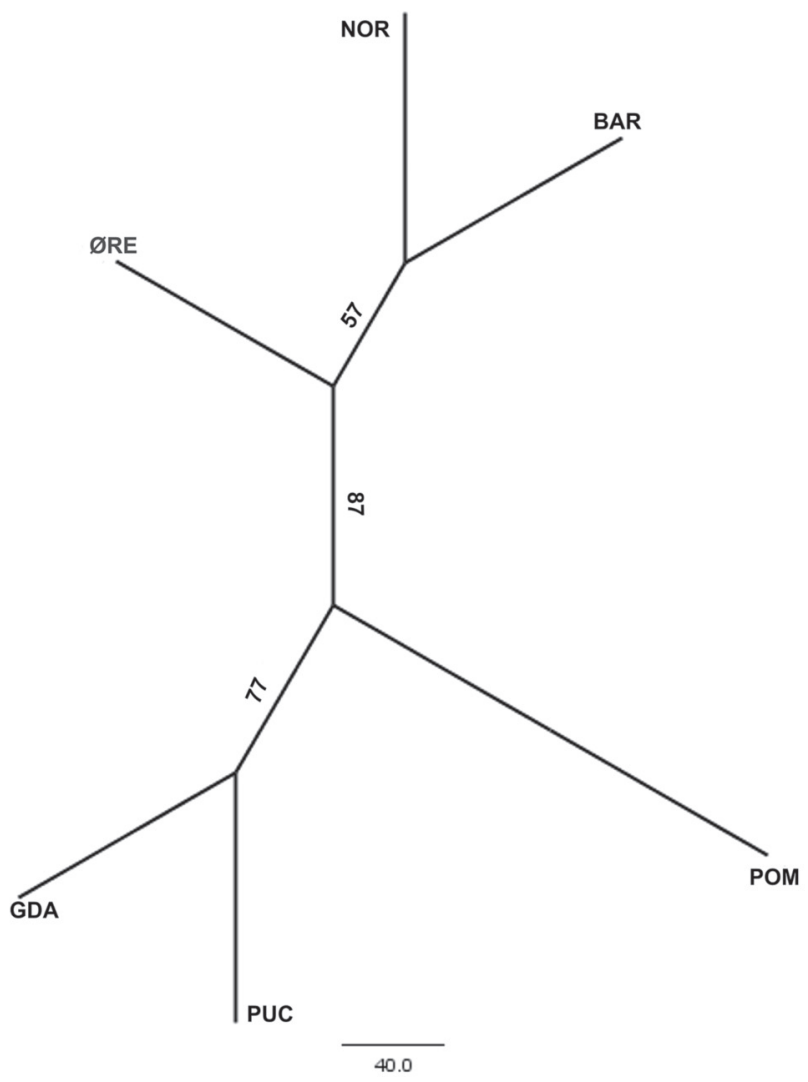

Fig. 2. Samples of cod, Gadus morhua, based on unrooted neighbour-joining tree inferred from Reynolds genetic distances; Only Baltic populations are differentiated with significant statistical support; GDA = Gdańsk Bay, PUC = Puck Bay, POM = Pomeranian Bay, $\varnothing \mathrm{RE}=$ Øresund, $\mathrm{NOR}=$ the North Sea, Flamborough Head, BAR = the Barents Sea

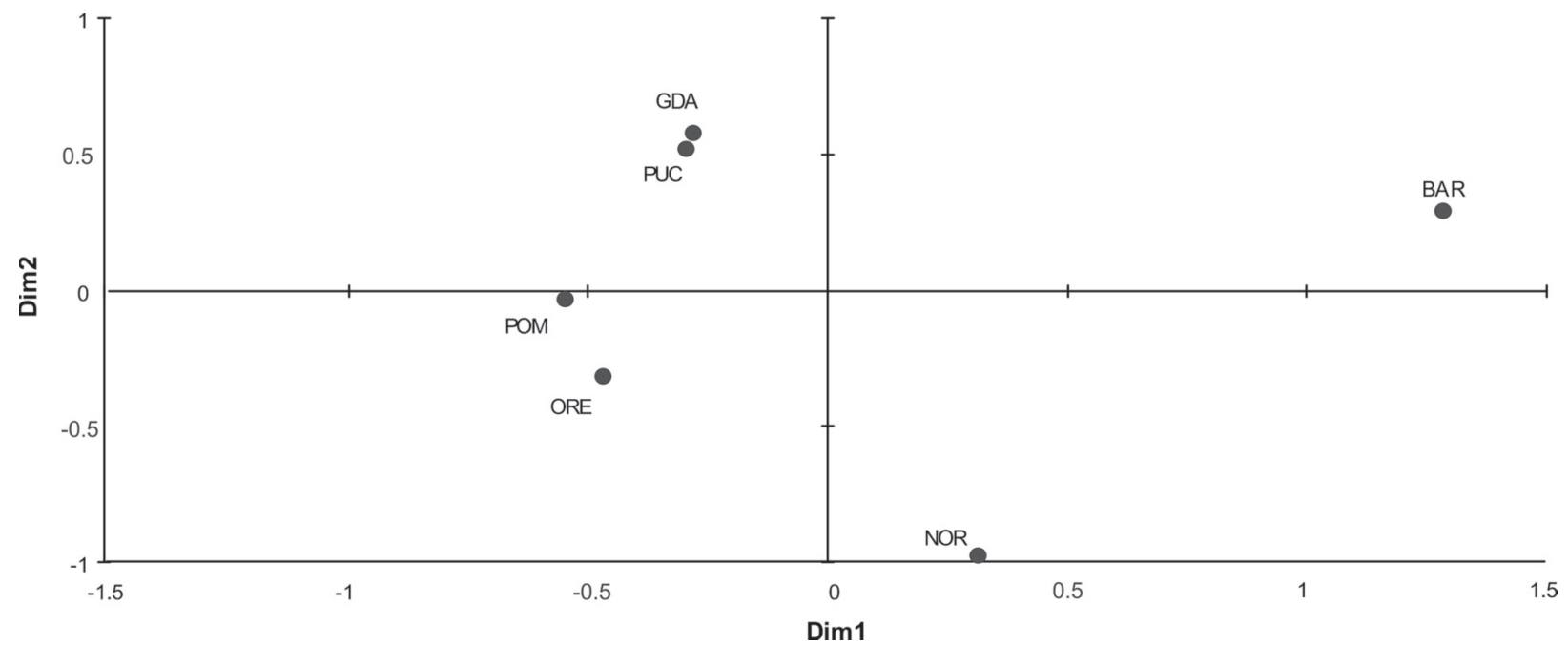

Fig. 3. Patterns of geographic structure in Atlantic cod, Gadus morhua, revealing multidimensional scaling (MDS) of matrix of genetic distances (D; Kruskal's stress = 0.104); GDA = Gdańsk Bay, PUC = Puck Bay, $\mathrm{POM}=$ Pomeranian Bay, ØRE $=$ Øresund, NOR $=$ the North Sea, Flamborough Head, BAR $=$ the Barents Sea 
two subspecies differing more from the Baltic samples than from the North samples (the North Sea and the Barents Sea pooled together). Pairwise $F_{\mathrm{ST}}$ for the Øresund sample and the North Sea sample is low (0.0253). Comparison of groups of populations revealed also that when the Baltic group is divided in two subgroups (Pomeranian Bay + Øresund and Puck Bay + The Gulf of Gdańsk) the pairwise $F_{\mathrm{ST}}(0.029)$ is higher than in case of any other grouping ( $F_{\mathrm{ST}}$ of all comparisons in range of $0.014-0.016)$. Contrary to this results the neighbour-joining (NJ) tree based on Reynolds genetic distances is less clear suggesting that sample from the Pomeranian Bay is closer related to two other Baltic samples than to Øresund sample. Nonetheless, statistical support for this topology is not conclusive and finally it is most probable that both samples, from the Pomeranian Bay and Øresund are exceptional due to localization inside the admixture zone.

The $F_{\mathrm{ST}}$ was highest for the Puck Bay vs. the Gulf of Gdańsk, and the Pomeranian Bay comparisons (0.071 and
0.063 , respectively). This could be an effect of small numbers of fish sampled and possible sampling bias (time of sampling, range of age, and depth of hauling) or the result of special status of the Puck Bay sample - its isolation makes it a potential nursery area. As it is shown in Table 3, the characteristic of the Puck Bay fish, in relation to six microsatellite loci, suggests strong differentiation between the Puck Bay- and neighbouring population. The main reason seems to be the fact that the Gulf of Gdańsk sample was collected during pre-spawning concentration (Aro 2000) of cod from the eastern Baltic, which were usually older (as confirmed by observed age classes), while the group of cod collected from the Puck Bay, were most probably feeding juveniles. Only two individuals reached the highest noted age in this group (IV) while standard range of age classes in other groups was mostly IV-VI (Table 3).

A separate problem in case of the Baltic group is situation of cod in relation to overfishing and progressing limitation of accessible spawning areas as an effect of

Table 5

Summary of genetic variation at six microsatellite loci of cod, Gadus morhua, collected from six sampling sites

\begin{tabular}{|c|c|c|c|c|c|c|c|c|}
\hline \multirow[b]{2}{*}{ Locus } & & \multicolumn{6}{|c|}{ Sampling site } & \multirow{2}{*}{$\begin{array}{c}\text { Mean } \\
N_{\mathrm{A}} / \text { locus }\end{array}$} \\
\hline & & PUC & POM & GDA & ØRE & BAR & NOR & \\
\hline \multirow[t]{4}{*}{ Gmo8 } & $N_{\mathrm{A}}$ & 8 & 12 & 12 & 19 & 22 & 22 & 15.83 \\
\hline & $H_{\text {exp }}^{\mathrm{A}}$ & 0.801 & 0.878 & 0.889 & 0.896 & 0.935 & 0.939 & \\
\hline & $H_{\text {obs }}^{\exp }$ & 0.179 & 0.560 & 0.593 & 0.760 & 0.679 & 0.905 & \\
\hline & $\stackrel{F}{F}$ & 0.777 & 0.362 & 0.334 & 0.151 & 0.274 & 0.036 & \\
\hline \multirow[t]{4}{*}{ Gmo19 } & $N_{\mathrm{A}}$ & 13 & 18 & 15 & 16 & 19 & 19 & 16.67 \\
\hline & $H_{\text {exp }}^{\mathrm{A}}$ & 0.926 & 0.926 & 0.923 & 0.883 & 0.925 & 0.937 & \\
\hline & $H_{\text {obs }}$ & 0.786 & 0.600 & 0.667 & 0.880 & 0.600 & 0.829 & \\
\hline & $F$ & 0.152 & 0.352 & 0.277 & 0.003 & 0.352 & 0.116 & \\
\hline \multirow[t]{4}{*}{ Gmo35 } & $N_{\mathrm{A}}$ & 9 & 7 & 10 & 12 & 9 & 9 & 9.33 \\
\hline & $H_{\text {exp }}^{\mathrm{A}}$ & 0.856 & 0.795 & 0.842 & 0.871 & 0.872 & 0.873 & \\
\hline & $H_{\text {obs }}^{\exp }$ & 0.393 & 0.440 & 0.515 & 0.510 & 0.347 & 0.615 & \\
\hline & $\stackrel{\text { oos }}{F}$ & 0.541 & 0.447 & 0.388 & 0.414 & 0.602 & 0.295 & \\
\hline \multirow[t]{4}{*}{ Gmo37 } & $N_{\mathrm{A}}$ & 17 & 16 & 14 & 18 & 16 & 17 & 16.33 \\
\hline & $H_{\text {exp }}^{\mathrm{A}}$ & 0.914 & 0.913 & 0.910 & 0.890 & 0.918 & 0.933 & \\
\hline & $H_{\text {obs }}^{\exp }$ & 0.714 & 0.680 & 0.568 & 0.700 & 0.600 & 0.884 & \\
\hline & $F$ & 0.219 & 0.255 & 0.376 & 0.213 & 0.346 & 0.053 & \\
\hline \multirow[t]{4}{*}{ Tch11 } & $N_{\mathrm{A}}$ & 14 & 14 & 14 & 23 & 18 & 18 & 16.83 \\
\hline & $H_{\text {exp }}^{\mathrm{A}}$ & 0.869 & 0.917 & 0.926 & 0.933 & 0.907 & 0.933 & \\
\hline & $H_{\text {obs }}^{\exp }$ & 0.714 & 0.680 & 0.609 & 0.660 & 0.625 & 0.756 & \\
\hline & F & 0.178 & 0.258 & 0.342 & 0.293 & 0.311 & 0.189 & \\
\hline \multirow[t]{8}{*}{ Tch12 } & $N_{\mathrm{A}}$ & 5 & 8 & 4 & 6 & 8 & 8 & 6.50 \\
\hline & $H_{\text {exp }}^{\mathrm{A}}$ & 0.600 & 0.810 & 0.675 & 0.727 & 0.745 & 0.409 & \\
\hline & $H_{\text {obs }}^{\exp }$ & 0.148 & 0.375 & 0.000 & 0.171 & 0.136 & 0.306 & \\
\hline & $\stackrel{\text { oos }}{F}$ & 0.753 & 0.537 & 1.000 & 0.764 & 0.817 & 0.252 & \\
\hline & Mean $N_{\mathrm{A}}$ & 11.00 & 12.50 & 11.50 & 15.67 & 15.33 & 15.50 & \\
\hline & Mean $H_{\exp }$ & 0.83 & 0.87 & 0.86 & 0.87 & 0.88 & 0.84 & \\
\hline & Mean $\mathrm{H}_{\text {obs }}$ & 0.49 & 0.56 & 0.49 & 0.61 & 0.50 & 0.72 & \\
\hline & $\mathrm{ML} F_{\mathrm{IS}}$ & $0.414^{*}$ & $0.368^{*}$ & $0.413^{*}$ & $0.294^{*}$ & $0.439 *$ & $0.147^{*}$ & \\
\hline
\end{tabular}

$\mathrm{PUC}=$ Puck Bay, POM $=$ Pomeranian Bay, GDA $=$ Gdańsk Bay, ØRE $=$ Øresund, BAR $=$ the Barents Sea, NOR $=$ the North Sea, Flamborough Head, $\mathrm{ML}=$ multilocus, $N_{\mathrm{A}}=$ number of alleles, $H_{\text {exp }}$ unbiased expected heterozygosity (Nei 1978), $H_{\mathrm{obs}}=$ observed heterozygosity, and $F=$ inbreeding coefficient; Chi-square significant values (bold) for $P<0.05$. Multilocus $F_{\mathrm{IS}},{ }^{*} P<0.01$. 
poor water inflows from the North Sea. In the Baltic Sea the salinity of surface waters decreases eastwards. It also increases with depth. Only the deepest areas of the southern Baltic Sea can serve as permanent breeding grounds for marine species. There are few such areas in the southern Baltic Sea namely the Bornholm and Gdańsk basins (Nissling et al. 2002). The above-mentioned limitations undoubtedly affect the population structure of cod, especially of eastern populations as those with decreased access to "permanent" spawning areas, through enforcement of spawning on one permanent spawning area which is the Bornholm zone. The Baltic cod homing behaviour has not been well studied but it is possible that cod may use different spawning grounds in successive years (Otterlind 1985). Published evidence indicates that cod spawning migration in the Baltic Sea is much more affected by prevailing hydrographical situation than by its homing instinct (Aro 2000).

Overfishing of Atlantic cod stocks in the Baltic Sea has been a permanent problem within the last two decades (Döring and Egelkraut 2008) and it can also influence the genetic structure of cod in the Baltic Sea by lowering the its recruitment. The genetic structure of cod can also be influenced by environmental variability when the spawning stock is low (Brander 2005). The poor condition of the eastern stock could be a result of higher homogeneity of eastern populations.

Generally, characterization of Baltic samples of cod reveals strong difference between eastern- and western samples. Undoubtedly the level of homogenization of eastern samples increases differentiation estimates to some degree as do the geographic isolation and accessibility of spawning areas of appropriate salinity and temperature. Also migration of the Atlantic cod from the North Sea has impact on the status of western Baltic cod population by mixing with "native" fish (Nielsen et al. 2003). On the other side, overfishing has an effect on isolation of individual stocks and consequently increases their differentiation. Nonetheless, there is a clear difference between eastern and western stock of Gadus morhua in Baltic suggesting the existence of separate stocks or even subspecies as it was postulated by Sick (1965) and Bleil and Oeberst (2002). In the future, genetic structure of Baltic cod should be carefully observed by all available procedures because of possible changes in the relation between G. morhua morhua and $G$. morhua callarias. In turn, this may affect significantly the level of cod biodiversity, and in effect, its sensitivity to the progressing changes of the environment.

\section{ACKNOWLEDGMENTS}

Authors thank Dr. Artur Burzyński from the Institute of Oceanology PAS for discussing key issues of this work.

\section{REFERENCES}

Árnason E. 2004. Mitochondrial cytochrome $b$ DNA variation in the high-fecundity Atlantic cod: Trans-Atlantic clines and shallow gene genealogy. Genetics 166 (4): 1871-1885. DOI: 10.1534/genetics.166.4.1871
Aro E. 2000. The spatial and temporal distribution patterns of cod (Gadus morhua callarias L.) in the Baltic Sea and their dependence on environmental variability-implications for fishery management. Academic dissertation. University of Helsinki, Finland.

Beacham T.D., Brattey J., Miller K.M., Le K.D., Withler R.E. 2002. Multiple stock structure of Atlantic cod (Gadus morhua) off Newfoundland and Labrador determined from genetic variation. ICES Journal of Marine Science 59 (4): 650-665. DOI: 10.1006/jmsc.2002.1253

Bleil M., Oeberst R. 2002. Spawning areas of the cod stock in the western Baltic Sea and minimum length at maturity. Archive of Fishery and Marine Research 49 (3): 243-258.

Brander K.M. 2005. Cod recruitment is strongly affected by climate when stock biomass is low. ICES Journal of Marine Science 62 (3): 339-343.

DOI: $10.1016 /$ j.icesjms.2004.07.029

Brookfield J.F.Y. 1996. A simple method for estimating null allele frequency from heterozygote deficiency. Molecular Ecology 5 (3): 453-455.

DOI: 10.1046/j.1365-294X.1996.00098.x

Case R.A.J., Hutchinson W.F., Hauser L., Van Oosterhout C., Carvalho G.R. 2005. Macro- and micro-geographic variation in pantophysin (PanI) allele frequencies in NE Atlantic cod Gadus morhua. Marine Ecology Progress Series 301: 267-278.

DOI: $10.3354 / \operatorname{meps} 301267$

Dahle G., Jørstad K.E. 1993. Haemoglobin variation in coda reliable marker for Arctic cod (Gadus morhua L.). Fisheries Research 16 (4): 301-311.

DOI: $10.1016 / 0165-7836(93) 90143-U$

Döring R., Egelkraut T.M. 2008. Investing in natural capital as management strategy in fisheries: The case of the Baltic Sea cod fishery. Ecological Economics 64 (3): 634-642. DOI: $10.1016 /$ j.ecolecon.2007.04.008

Excoffier L., Laval G., Schneider S. 2005. Arlequin (version 3.0): An integrated software package for population genetics data analysis. Evolutionary Bioinformatics Online 1: 47-50.

Eikeset A.M., Hjermann D.Ø., Dunlop E., Stenseth N.Chr., Ottersen G., Olsen E.M., Dieckmann U. 2005. Fisheries-induced evolution in Northeast Arctic cod. Pp. 284-285. In: 2005 ICES Annual Science Conference: Cod in a Changing Climate. Session AA 16. www.ices.dk/iceswork/asc/2005/Abstracts/AA/AAlist.pdf.

Felsenstein J. 2004. Phylip (Phylogeny Inference Package v 3.6). University of Washington, Seattle WA, USA. http://evolution.genetics.washington.edu/phylip.html.

Gaggiotti O.E., Lange O., Rassmann K., Gliddon C. 1999. A comparison of two indirect methods for estimating average levels of gene flow using microsatellite data. Molecular Ecology 8 (9): 1513-1520. DOI: 10.1046/j.1365-294x.1999.00730.x

Hoarau G., Rijnsdorp A.D., Van Der Veer H.W., Stam W.T., Olsen J.L. 2002. Population structure of plaice (Pleuronectes platessa L.) in northern Europe: microsatellites revealed large-scale spatial and temporal homogeneity. Molecular Ecology 11 (7): 1165-1176. DOI: 10.1046/j.1365-294X.2002.01515.x 
Hutchinson W.F., van Oosterhout C., Rogers S.I., Carvalho G.R. 2003. Temporal analysis of archived samples indicates marked genetic changes in declining North Sea cod (Gadus morhua). Proceedings of the Royal Society of London, Series B 270 (1529): 2125-2132.

DOI: $10.1098 /$ rspb.2003.2493

Jónsdóttir Ó.D.B., Imsland A.K., Daníelsdóttir A.K., Thorsteinsson V., Nævdal G. 1999. Genetic differentiation among Atlantic cod in south and south-east Icelandic waters: synaptophysin (Syp I) and haemoglobin $(H b I)$ variation. Journal of Fish Biology 54 (6): 1259-1274. DOI: $10.1111 /$ j.1095-8649.1999.tb02053.x

Karlsson S., Mork J. 2005. Deviation from Hardy-Weinberg equilibrium, and temporal instability in allele frequencies at microsatellite loci in a local population of Atlantic cod. ICES Journal of Marine Science 62 (8): 1588-1596.

DOI: 10.1016/j.icesjms.2005.05.009

Knutsen H., Jorde P.E., André C., Stenseth N.C. 2003. Finescaled geographical population structuring in a highly mobile marine species: the Atlantic cod. Molecular Ecology 12 (2): 385-394.

DOI: 10.1046/j.1365-294X.2003.01750.x

Marteinsdóttir G., Ruzzante D., Nielsen E.E. 2005. History of the north Atlantic cod stocks. 2005 ICES Annual Science Conference: Cod in a Changing Climate. Session AA: 19. www.ices.dk/iceswork/asc/2005/Abstracts/AA/AA-list.pdf.

Mork J., Ryman N., Stahl G., Utter F., Sundnes G. 1985. Genetic variation in Atlantic cod (Gadus morhua) throughout its range. Canadian Journal of Fisheries and Aquatic Sciences 42 (10): 1580-1587.

DOI: $10.1139 / \mathrm{f} 85-198$

Nei M. 1983. Genetic polymorphism and the role of mutation in evolution. Pp. 165-190. In: Nei M., Koehn R. (eds.) Evolution of genes and proteins. Sinauer Associates, Sunderland, MA, USA.

Nei M. 1978. Estimation of average heterozygosity and genetic distance from a small number of individuals. Genetics 89 (3): 583-590.

Nielsen E.E., Hansen M.M., Ruzzante D.E., Meldrup D., Grønkjær P. 2003. Evidence of a hybrid-zone in Atlantic cod (Gadus morhua) in the Baltic and the Danish Belt Sea revealed by individual admixture analysis. Molecular Ecology 12 (6): 1497-1508. DOI: 10.1046/j.1365-294X.2003.01819.x

Nissling A., Westin L., Hjerne O. 2002. Reproductive success in relation to salinity for three flatfish species, dab (Limanda limanda), plaice (Pleuronectes platessa), and flounder (Pleuronectes flesus), in the brackish water Baltic Sea. ICES Journal of Marine Science 59 (1): 93-108.

DOI: $10.1006 /$ jmsc.2001.1134

O'Leary D.B., Coughlan J., McCarthy T.V., Cross T.F. 2006. Application of a rapid method of SNP analysis (glycosylase mediated polymorphism detection) to mtDNA and nuclear DNA of cod Gadus morhua. Journal of Fish Biology 69 (Suppl. SA): 145-153.

DOI: $10.1111 / \mathrm{j} .1095-8649.2006 .01158 . x$
O'Leary D.B., Coughlan J., Dillane E., McCarthy T.V., Cross T.F. 2007. Microsatellite variation in cod Gadus morhua throughout its geographic range. Journal of Fish Biology 70 (Suppl. SC): 310-335.

DOI: $10.1111 / \mathrm{j} .1095-8649.2007 .01451 . \mathrm{x}$

O'Reilly P.T., Canino M.F., Bailey K.M., Bentzen P. 2000. Isolation of twenty low stutter di- and tetranucleotide microsatellites for population analyses of walleye pollock and other gadoids. Journal of Fish Biology 56 (5): 1074-1086.

DOI: $10.1111 / j .1095-8649.2000 . t b 02124 . x$

Otterlind G. 1985. Cod migration and transplantation experiments in the Baltic. Zeitschrift fur Angewandte Ichthyologie 1 (1): 3-16.

Pogson G.H., Mesa K.A., Boutilier R.G. 1995. Genetic population structure and gene flow in the Atlantic cod Gadus morhua: a comparison of allozyme and nuclear RFLP loci. Genetics 139 (1): 375-385.

Pogson G.H., Taggart C.T., Mesa K.A., Boutilier R.G. 2001. Isolation by distance in the Atlantic cod, Gadus morhua, at large and small geographic scales. Evolution 55 (1): 131-146.

Raymond M., Rousset F. 1995. GENEPOP (version 1.2): population genetics software for exact tests and ecumenicism. Journal of Heredity 86 (3): 248-249. http://kimura.univmontp2.fr/ rousset/Genepop.htm.

Reynolds J.B., Weir B.S., Cockerham C.C. 1983. Estimation of the coancestry coefficient: basis for a short-term genetic distance. Genetics 105 (3): 767-779.

Saitou N., Nei M. 1987. The neighbor-joining method: a new method for reconstructing phylogenetic trees. Molecular Biology and Evolution 4 (4): 406-425.

Sambrook J., Fritsch E.F., Maniatis T. 1989. Molecular cloning: a laboratory manual. Cold Spring Harbor Laboratory Press, New York, NY, USA.

Sick K. 1965. Haemoglobin polymorphism of the cod in the Baltic Sea and in the Danish Belt Sea. Hereditas 54 (1): 19-48.

DOI: $10.1111 / j .1601-5223.1965 . t b 02004 . x$

Sobecka E. 2007. Parasites of Atlantic cod (Gadus morhua morhua L. and Gadus morhua callarias L.) from the chosen regions of the Atlantic and the Baltic Sea. Academic dissertation No. 245, Agricultural University of Szczecin, Poland. [In Polish, with English summary.]

Weir B.S., Cockerham C.C. 1984. Estimating F-statistics for the analysis of population structure. Evolution 38 (6): 1358-1370.

DOI: $10.2307 / 2408641$

Received: 30 April 2011

Accepted: 5 December 2011

Published electronically: 31 December 2011 